\title{
Reasons to be hopeful: Learning and becoming in a time of crisis
}

\author{
Paul Stanistreet ${ }^{1}$ \\ Published online: 18 August 2021 \\ (c) UNESCO Institute for Lifelong Learning and Springer Nature B.V. 2021
}

The United Nations Intergovernmental Panel on Climate Change's stark and sobering new report (IPCC 2021) ${ }^{1}$ on the climate emergency was published on 9 August 2021. It was launched as wildfires devastated parts of Greece, and just a few weeks after catastrophic flooding claimed hundreds of lives in Asia and Central Europe, and the West Coast of North America experienced an unprecedented leap in record temperatures. The much-circulated images of people being evacuated by ferry from forest fires on the Greek island of Evia (BBC 2021), ${ }^{2}$ the sky behind them a shade of red best described as apocalyptic, may well be among the defining images of our era, a vivid indicator of our failure to act on climate change when we had the chance. However, as the IPCC report makes clear, this need not be the case. Although we are uncomfortably late in acting, and many of the changes we are seeing are "irreversible", at least in the short and medium term, it is not yet too late, and there is still much we can do, and much we can save. As Inger Andersen, Executive Director of the United Nations Environment Programme, noted at the report's launch, "the power is in our hands at this point", and there is an onus on every business leader, politician and policymaker "to consider how to be a contributor" (Bedigan 2021). ${ }^{3}$

The IPCC report - the definitive and uniquely authoritative word on the physical causes of global warming - finds it "unequivocal" that human activity is the cause

\footnotetext{
${ }^{1}$ IPCC (Intergovernmental Panel on Climate Change) (2021). Climate change 2021: The physical basis. Geneva: IPCC. Retrieved 12 August 2021 from https://www.ipcc.ch/report/sixth-assessment-reportworking-group-i/?_cff_chl_jschl_tk_=pmd_436170e1cd5da795dfd7b4d338014c3d821ab809-16285 07920-0-gqNtZGzNAg2jenBszQrO.

${ }^{2}$ BBC (British Broadcasting Corporation) (2021). Hundreds rescued by ferry from Greece wildfires [BBC, 7 August; online news item]. Retrieved 12 August 2021 from https://www.bbc.com/news/av/ world-europe-58128034.

${ }^{3}$ Bedigan, M. (2021). World "listened, but did not hear" on climate crisis - UN environment chief [msn news, 9 August; online news item]. Retrieved 12 August 2021 from https://www.msn.com/en-gb/ news/uknews/world-listened-but-did-not-hear-on-climate-crisis-\%E2\%80\%93-un-environment-chief/arAAN6ACz.
}

Paul Stanistreet

p.stanistreet@unesco.org

1 UNESCO Institute for Lifelong Learning, Hamburg, Germany 
of climate change, making extreme climate events, including heatwaves, heavy rainfall and drought both more frequent and more severe. We should expect extreme weather events to become more common in the coming decades, worsening with further human-influenced rises in temperature. Already, every region in the world is experiencing some combination of rising temperatures, forest fires, flood or drought, the report says. Only "strong, rapid, and sustained" reductions in greenhouse gas emissions, and attaining net zero $\mathrm{CO}_{2}$ emissions in this decade will prevent further climate breakdown and limit global warming to $1.5^{\circ} \mathrm{C}$. With $1.5^{\circ} \mathrm{C}$ of global warming, we can expect increasing heat waves, longer warm seasons and shorter cold seasons. For every additional amount of global warming, the IPCC warns, changes will be on a larger scale, extreme weather events will become more common and human life on the planet more precarious.

It is easy to be despondent, even despairing, in the face of such a damning indictment of political and corporate failure, pig-headedness and indifference. Yet the report is a hopeful one, in a sense, because it places in the hands of citizens the opportunity to make things right and act decisively and ambitiously, as the report insists we must. It represents an unchallengeable mandate for far-reaching change, not just in national emissions policies, or in terms of the forms of energy we use to heat and light our homes and power our factories, but in every aspect of the way in which we live, including, quite crucially, in education. We have an opportunity, surely the last we will have (this, as they say, is our window), to create societies that are sustainable and humane, and education systems focused on producing active, mindful citizens who see themselves not as consumers or workers in an economy detached from their natural environment but as conscious actors in a complex, interconnected and co-dependent ecosystem, with obligations to other people, their communities and the natural world. For this to happen, education must be lifelong and life-wide, open-ended and holistic, animated by creativity and common purpose. We need to reimagine lifelong learning from a different place.

Lifelong learning not only needs to be a part of this change, providing a crucial dimension of the kind of world we want to create; it also has a critical, multi-faceted role in creating it. First, and most straightforwardly, lifelong learning is required to raise awareness of climate change and of the actions people must take to reduce emissions and live more sustainably. We need to promote climate literacy and give people the skills and knowledge they need to change their behaviour and their communities in meaningful ways. This means understanding the complex nature of the climate emergency, its links to poverty and inequality, the role of capital and technology and what it would mean to bring emissions to net zero and develop a truly green economy. We cannot solve the problems of climate change through individual action, though it can have an impact (especially if the individual in question is a billionaire with a space rocket). We have to think together, with a focus on the systemic. We cannot afford any more to think in silos or to pretend that climate change can be addressed without also considering questions of economics, social justice, discrimination, inequality and, yes, education. For educators, this means accepting a broader understanding of the purposes of our work and of our responsibilities to our students, educationally and in terms of their safety and well-being. 
Second, and relatedly, lifelong learning must empower people and give them the skills they need to demand change and be part of it, to galvanise political will and challenge and change mindsets. One of the findings of the fourth Global Report on Adult Learning and Education (UIL 2019) ${ }^{4}$ was that active citizenship was neglected in comparison to the other main dimensions of learning: literacy and basic skills, and continuous training and professional development. ${ }^{5}$ This has to change, even if it means the reversal of several decades of policy-making premised on the idea that lifelong learning is essentially "an investment in economic development" (Biesta 2006, p. 169) ${ }^{6}$ It is clear that the challenge of the climate crisis will not be met through the unpressured actions of politicians and corporations. We should not look hopefully for solutions towards the people whose actions and inaction have driven the current crisis. We need instead an informed, active citizenry, armed with new knowledge, animated and empowered by their engagement in adult and popular education to believe that change is possible. Such change can only come from the bottom up, and that demands the sort of citizen engagement that lifelong learning is best placed to foster. In Gert Biesta's words, we must reclaim "those forms of collective learning - learning with others and from otherness and difference - which are linked to empowerment, collective action and social change, and to the translation of our private troubles into collective and shared concerns" (ibid., p. 170).

Third, lifelong learning must embody the kind of change we need to see in wider society. It has a crucial role to play in developing shared meaning and common cause around climate. It must enable people to see further and to act together, reaching beyond narrow individualism. It must, in the best traditions of adult education, foreground dialogue and co-production of knowledge, and offer hope and the prospect of social change. It must support people to learn and think together in ways oriented towards the common good, and encourage reflection not only on the working parts of the system but on the interdependencies between them. The promise of UNESCO's Futures of Education initiative to reorient education "towards building capacity for commoning [sic] actions and strengthening the common good" (Sobe $2021)^{7}$ is a source of hope, as is its willingness to rethink humanism (Facer 2021) and revert to Indigenous knowledge (Moore and Nesterova 2020). ${ }^{9}$ The latter is

\footnotetext{
${ }^{4}$ UIL (UNESCO Institute for Lifelong Learning) (2019). Leave no one behind: Participation, equity and inclusion. Fourth Global Report on Adult Learning and Education. Hamburg: UIL. Retrieved 12 August 2021 from https://unesdoc.unesco.org/ark:/48223/pf0000372274.

5 Active (global) citizenship education will be the focus of the Fifth Global Report on Adult Learning and Education, which is scheduled for publication in 2022.

6 Biesta, G. (2006). What's the point of lifelong learning if lifelong learning has no point? On the democratic deficit of policies for lifelong learning. European Educational Research Journal, 5(3-4), 169-180. https://doi.org/10.2304/eerj.2006.5.3.169.

7 Sobe, N.W. (2021). Reworking four pillars of education to sustain the commons [UNESCO Futures of Education Ideas LAB, 10 February; online article]. Retrieved 12 August 2021 from https://en.unesco.org/ futuresofeducation/ideas-lab/sobe-reworking-four-pillars-education-sustain-commons.

${ }^{8}$ Facer, K. (2021). Rethinking the "human" at the heart of humanist education [UNESCO Futures of Education Ideas LAB, 26 March; online article].Retrieved 12 August 2021 from https://en.unesco.org/ futuresofeducation/ideas-lab/facer-rethinking-humanist-education.

9 Moore, S.J., \& Nesterova, Y. (2020). Indigenous knowledges and ways of knowing for a sustainable living. Background paper for the Futures of Education initiative. Paris: UNESCO. Retrieved 12 August 2021 from https://unesdoc.unesco.org/ark:/48223/pf0000374046.
} 
especially important. As Miye Nadya Tom, Elizabeth Sumida Huaman and Teresa L. McCarty note in their introduction to a 2019 special issue of this journal, Indigenous knowledges have a critical role to play in reframing "dominant discourses of development and globalisation while challenging colonially entrenched neoliberal forms of oppression" (Tom et al. 2019, p. 14). ${ }^{10}$ They represent humanity's greatest store of knowledge, skills and philosophies about how to live with and within the natural environment (UNESCO n.d.). ${ }^{11}$ If the old, discredited orthodoxies of endless economic growth and limitless consumption are not to take us all with them, we need to look beyond them to "find a new language of hope, founded on planetary sustainability, collective action and a commitment to equitable and inclusive futures" (Stanistreet 2021). ${ }^{12}$

Embracing Indigenous culture and ideas means supporting Indigenous learning and removing the barriers faced by Indigenous learners, some of them emerging from the kind of "colonial enmeshment" described by Tom, Huaman and McCarty (Tom et al. 2019, p. 14). A large part of this concerns respect for Indigenous traditions and the delivery of education in Indigenous languages, the topic of the first article of this issue. In "Language of instruction: Concerning its choice and social prestige in Burkina Faso", Melanie David-Erb reviews the latest research on language in education in sub-Saharan Africa, and asks why Indigenous languages are so rarely used in formal schooling in this region, despite political demands for their greater use and evidence of their positive impact. Burkina Faso, the focus of the article, exemplifies this seemingly contradictory situation. Indigenous languages and French are complementary in formal and non-formal schooling as well as in areas of informal education; however, a closer look at the areas of application of each language reveals that Indigenous languages have lower social prestige than French, as well as lower expected and required outcomes.

One of the criticisms of citizenship education in the past has concerned its tendency to produce apathetic or nationalistic citizens, or to reproduce existing systems of inequality and injustice. For this reason, it is important that education for active citizenship both transcends national boundaries and respects and fosters the agency and self-identity of learners, treating citizenship not as an uncontested body of customs and beliefs but as an arena of critical engagement over which we all have a say. Recognising the sense of identity and unique needs and capabilities of different groups of learners is an essential part of adult education practice. The second article of the issue, "Compuabuelitos/Technogrands: An intergenerational experience based on Pierre Faure's pedagogy", concerns the challenge of developing approaches in

\footnotetext{
10 Tom, M.N., Sumida Huaman, E., \& McCarty, T.L. (2019). Indigenous knowledges as vital contributions to sustainability. International Review of Education 65(1), 1-18. https://doi.org/10.1007/s11159019-09770-9.

11 UNESCO (n.d.) What is local and indigenous knowledge? [item on dedicated webpage "Local and Indigenous Knowledge Systems"]. Retrieved 12 August 2021 from http://www.unesco.org/new/en/natur al-sciences/priority-areas/links/related-information/what-is-local-and-indigenous-knowledge/.

12 Stanistreet, P. (2021). Meditations on an emergency [Only connect, 18 July; blog post]. Retrieved 12 August 2021 from https://thelifelonglearningblog.uil.unesco.org/2021/07/18/meditations-on-an-emerg ency/.
} 
education which respect older learners' individual characteristics and capacities. Written by Susana Maria Aldaco-Arias and Juan Carlos Silas-Casillas, the article describes a Mexican project in which teenagers taught their own grandparent (or another elderly person they knew) basic cell phone technology skills. While projects of this kind have been run in schools in other countries with positive results, the distinctive feature of this intervention was that the adolescents received training about older people's needs prior to engaging with them, using a learner-centred pedagogical model created by French Jesuit Pierre Faure. The model is based on respecting learners' individual characteristics and desired pace of learning, and their own selflearning and decision-making capacities. The teenagers applied these principles to the course they taught with great success, not only helping their trainees achieve learning targets, but also cultivating closer relationships with them. They attributed the success of the project to their use of language which was appropriate for their third-age learners, adapting their teaching style to older people's characteristics and creating a supportive learning environment.

The third item featured in this issue is a research note which also explores questions of learner agency and empowerment. "A bottom-up approach to improve women's access to technical and vocational education and training in India: Examining a non-formal education upskilling programme", by Matthew A. Witenstein and Radhika Iyengar, shares insights from the first stages of the authors' study of an upskilling programme in the non-formal education sector in India. The Indian Government has ambitious plans to upskill women and support their access to technical and vocational education and training (TVET) but, they note, there is much work to be done to fulfil these plans, while achieving them in a socially just manner demands greater efforts to include and amplify women's voices throughout the process. The authors argue for a bottom-up approach to appreciate how women wish to participate in TVET. To understand the women's perspectives, the authors use the notions of third-space frameworks and "scapes" which go beyond simply acknowledging the need for labour upskilling and offer opportunities to critique gender biases, stereotypes and patriarchal practices, while formulating new ideas about how to engage as active participants in Indian society. Based on these insights, the authors offer a path forward by directly engaging with women on the ground level, using a bottom-up approach to develop policy that supports their needs, desires and aspirations.

Listening to adult learners, and particularly those from groups traditionally excluded from education, plays an important role in fostering engagement and preventing dropout, as well as being a straightforward matter of social justice. It is also a critical part of seeing education as a lifelong developmental process that supports people in adapting to change throughout and across life, at home, in the workplace or in the community. One barrier to realising this vision of educational possibility is explored in the next article, "From deficit to apposite: A critique of NEET constructions of out-of-school youth in Eswatini (formerly Swaziland)". Tibekile A. Manana and Peter N. Rule examine the term "NEET" as a description of young people who are not in employment, education or training, and consider its tendency to reinforce social and economic exclusion and stigma. Based on a narrative study which used focus-group discussions and questionnaires to 
investigate the educational experiences of 55 out-of-school youth, the article argues that the "NEET" label is reductive of young people's potential and sidelines their contributions to their families, communities and wider society by framing them in terms of deficiency. The authors propose an alternative which, they argue, better captures young people's agency and situatedness in an African context. This concept, which regards young people "as living holistic, fulfilling and meaningful lives within their family, community and society, rather than as mere instruments or objects for meeting the needs of the market economy", may contribute to reimagining the relationship between formal and informal learning and livelihoods, and between Western and African knowledge systems, in Eswatini and other developing countries.

Just as learners are complex, so too are the outcomes of their learning; yet too often we approach this is in a similarly reductive way. The fifth article of this issue is entitled "EduIMPACT: A scale for measuring the impact of literacy programmes for youth and adults". Authored by Oscar Iván Gutiérrez-Carvajal, Mónica Perdomo, Jenny Lorena Agredo and Geisler Dayani Rojas, it considers the impact of participation in learning and proposes a new instrument for measuring the effectiveness of literacy programmes for youth and adults. To assess the impact of participation on individual learners' lives and their environment, the authors developed a structure comprising five main dimensions: (1) "personal sphere"; (2) "social skills"; (3) "life project"; (4) "knowledge"; and (5) "economic situation". The first phase of development of the instrument involved definition of the dimensions and a series of focus group discussions and interviews with students, teachers and managers from a Colombian second-chance adult education programme. In the second phase, six specialists in education and psychology validated the survey items in an expert trial, while, in the third, the authors finalised a survey questionnaire to test their scale and distributed it among programme graduates. In their analysis of the results, the authors found that their instrument, which they named EduIMPACT, had proved useful in evaluating the programme and understanding its impact across a wide range of dimensions and sub-dimensions.

The last item in this issue, "Interdisciplinary education and authentic development", is a research note by Alberto Ciferri and Angelaurelio Soldi. It outlines an educational approach to promote authentic development, the authors' own concept "for the successful promotion of harmony and stability within today's multi-ethnic communities". This new discipline, they argue, "should be taught through and based on principles conducive to achieving harmonious economic development paced to social development, able to mitigate ethnic and class conflicts and foster evolved, rather than uprooted, cultural values". The authors propose interdisciplinary courses that include notions of history, sociology and economy. Their methodology is based on two main resources: (1) a textbook providing a broad historical survey tracing the development of 28 nations in the Americas; and (2) analytical parameters related to the extent of social interaction and income generation. Students carry out digital and group research and elaborate the conditions that generate social harmony, economic well-being and a better balance between them. The authors have already piloted their educational approach in four secondary schools in Antigua, Guatemala, with 50 students aged between 17 and 19. Most of them are now enrolled at local 
universities; however, as the study acknowledges, the impact of the course on their performance will only emerge over time.

The authors highlight, among other things, the need for education "to develop independent analytical thinking in learners and even inspire them to produce original work". This is important, given the huge challenges facing humanity, most notably the climate emergency. As we begin to emerge from the current pandemic crisis, we need to do more than rebuild and renew our damaged systems of education. We need education not for the world that was or is, but for the world that could be, the future we want to create. That is why it is so critical that education gives us reasons to hope, and the resources and capabilities we need to challenge and critique, and to think and act together to build something new. It is also why I find the Futures of Education initiative's notion of "learning to become" particularly promising. ${ }^{13} \mathrm{We}$ need to reframe lifelong learning in terms of building capacity to act together for the common good, promoting a vision of education that is not just about learning to be, but learning to become, together. Learning must be a collective process that emphasises "learning to care for each other, for different communities and for the planet" (UIL 2020, p. 8). ${ }^{14}$ The catastrophic events of the past month are a wake-up call - the IPCC report is "a code red for humanity", says United Nations Secretary-General António Guterres (McGrath 2021). ${ }^{15}$ As I write, wildfires are causing death and destruction in northern Algeria. There are no safe zones, no exemptions, no variation of the old normal that we can responsibly pursue. We are connected by our shared vulnerability. Hope lies in our acknowledging this and finding ways to make common cause and locate shared responsibility, in rediscovering "collective learning ... linked to empowerment, collective action and social change" and a new normal of sustainable living. The decade of action has already begun and, unless we can make that hope a reality, the future looks bleak indeed.

Publisher's Note Springer Nature remains neutral with regard to jurisdictional claims in published maps and institutional affiliations.

\footnotetext{
13 For more information on UNESCO's Futures of Education: Learning to Become initiative, see https:// en.unesco.org/futuresofeducation/ [accessed 12 August 2021].

14 UIL (UNESCO Institute for Lifelong Learning) (2020). Embracing a culture of lifelong learning: Contribution to the Futures of Education initiative. Hamburg: UIL. Retrieved 12 August 2021 from https://unesdoc.unesco.org/ark:/48223/pf0000374112.

15 MdGrath, M. (2021). Climate change: IPCC report is "code red for humanity“ [BBC, 9 August; online news item]. Retrieved 12 August 2021 from https:/www.bbc.com/news/science-environment-58130705.
} 